\title{
Comparison of Crestal Bone Levels of Prevail Implants with Platform-Switched: Following One Year
}

\author{
Pablo Correa $\mathbf{E}^{1^{*}}$, Camilo Lopez ${ }^{2}$ \\ ${ }^{1}$ DDS, CES University. Oral and Maxilofacial Surgeon, Pontifical Javeriana University. Postgraduate Program \\ Director of the Dental School, CES University, Medellin, Colombia \\ ${ }^{2}$ DDS, CES University. Oral and Maxilofacial Surgeon, CES University, Medellin, Colombia

\begin{abstract}
*Corresponding Author: Pablo Correa E, DDS, CES University. Oral and Maxilofacial Surgeon, Pontifical Javeriana University. Postgraduate Program Director of the Dental School, CES University, Medellin,
\end{abstract} \\ Colombia; Email: correap@hotmail.com
}

Received Date: 27-07-2021; Accepted Date: 16-08-2021; Published Date: 23-08-2021

Copyright $^{\odot} 2021$ by Pablo CE. All rights reserved. This is an open access article distributed under the terms of the Creative Commons Attribution License, which permits unrestricted use, distribution and reproduction in any medium, provided the original author and source are credited.

\begin{abstract}
Purpose: To evaluate the changes in the bone crest around the implants with abutments with platform-switched in a retrospective clinical investigation derived from a previous study.

Materials and Methods: Twenty-six healthy patients mean age of 51,6 $\pm 11,4$ with one or more missing teeth were consecutively treated with Prevail implants, with and without platformswitched, conical, and with complete treatment. A total of 68 implants were placed test group with a prevailing implant with platform-switched (34 implants) and control group with the prevailing implant without platform-switched (34 implants). The final restorations were delivered 4 to 11 months after the insertion of the implant. Digital standardized periapical radiographs using customized film holders were obtained at the time of implant insertion and 12 months after. Marginal levels of peri-implant bone were measured on the mesial and distal surfaces of each implant using digital imaging software.
\end{abstract}

Results: All the osseo integrated implants were clinically stable at the 12-month follow-up. The cumulative survival rate was $100 \%$. The average bone loss was $1,34 \pm 1,02 \mathrm{~mm}$ on mesial and $1,57 \pm 0,99 \mathrm{~mm}$ on distal for the control group and $0,56 \pm 0.85 \mathrm{~mm}$ on mesial and $0,82 \pm 0,92$ $\mathrm{mm}$ on distal for the test group. There are no significant differences related to sex, implant site, and bone density.

Pablo CE | Volume 2; Issue 2 (2021) | JDHOR-2(2)-031 | Research Article

Citation: Pablo CE. Comparison of Crestal Bone Levels of Prevail Implants with Platform-Switched:

Following One Year. J Dental Health Oral Res. 2021;2(2):1-13.

DOI: http://dx.doi.org/10.46889/JDHOR.2021.2206 
Conclusion: The results of this study suggest that using implants with platform-switched may be effective in conserved the crestal bone level, reducing bone loss, and preserving the aesthetics of peri-implant tissues.

\section{Keywords}

Bone Preservation; Crestal Bone Level; Dental Implant; Platform Switching

\section{Introduction}

A dental implant is a structure made of alloplastic materials implanted in oral tissues under the mucosa and/or periosteum and/or inside or through the bone, to provide retention and support of a fixed or removable denture [1]. Proper knowledge of anatomical benchmarks and their variations before implant placement is indispensable to ensure an accurate surgical procedure and protect the patient from iatrogenic complications.

Development in the field of implant dentistry has involved the study of better Bone-Implant Contact (BIC) and the use of predictable surgical techniques and prosthetic treatments [2]. Predictability problems are paramount in the patient's decision to undergo implant prosthetic therapy. The dentist-rehabilitator, together with the surgical team, should adequately inform patients of the relative success rates of various implant systems and the prognosis that can be applied to each implant and prosthetic treatment system.

The respective BICs of different implant designs and surfaces have used animal and human models [3,4]. A human histomorphometric analysis comparing the surface of Osseotite ( $\mathrm{HCl} / \mathrm{H} 2 \mathrm{SO} 43 \mathrm{i}$ implant engraved with acid [Osseotite: ImplantInnovations, 3i: West Palm Beach, FL, USA]), with a conventional polishing titanium surface demonstrates a continuous BIC factor in the Osseotite implant ${ }^{\circledR}$ compared to the non-continuous BIC factor of conventional polishing implant [5]. This human study shows that the surface of the Osseotite rough implant is ossomalred at higher BIC levels (more than $92 \%$ of the time) compared to conventional polished implants is compatible with animal studies [6].

Crestal bone loss is a potential complication factor that affects implants [7]. The causes of such loss are attributed to several factors, although the evidence is not conclusive. Several authors [8,9]. Propose that it is the result of a combination of effects including limited milling procedure and restricted second phase surgery, rough implant surface in the crest bone, micro thread design for implant stiffness, load on a cone interface compared to a plana and absence of a significant microspace [10-14]. 
The dental implant is placed intraoseally and must have specific conditions that may be organic and inorganic in nature and both can potentially influence cellular activity during peri-implant healing. In this context, many types of surface coatings have been analyzed in recent years. These include coatings with Extracellular Matrix Proteins (ECMs), peptides, growth factors, calcium phosphate, lipids, among others. In animal studies, the application of high doses of the BMP-210 growth factor, as well as other approaches using ECM components such as collagen and glucosaminoglycans or ECM protein-derived peptides, have been reported to show an effect on bone healing $[14,15]$.

The implant is intended to achieve a biological width suitable for the healthy existence of bone and soft tissue from the more apical end of crown-implant restoration $[15,16]$. The increasing amount of anecdotal evidence in relation to platform change supports this biological width hypothesis. In this case, the biological width refers to the height of the dentogingival fixation apparatus around a normal dental part and is defined as the distance necessary for the healthy existence of bone and soft tissue from the most apical end of a dental restoration $[17,18]$.

The practice of changing platforms (e.g. placing a $4 \mathrm{~mm}$ pillar on a $5 \mathrm{~mm}$ implant settlement surface) results in a physical separation between the inflammatory cell infiltration zone and the crestal bone [19]. The platform change in dental implantology occurs when the prosthetic part of the implant is wider than the prosthetic pillar in the settlement area; otherwise, the dimensions of these attachments are similar. This change minimizes bone loss while allowing soft tissue support and is key to optimal aesthetics and papilla maintenance, even if two nearby implants are placed in the previous sector [20].

The Prevail implant has an integrated and medialized settlement surface, which consists of a unique structure that in the abutment/implant junction exhibits a slight angulation that supports connective tissue, this establishes a platform change function [21-23]. This implant moves the implant/pillar interface away from the crestal bone and therefore may reduce the amount of bone loss seen when using the standard (non-medialized) Osseotite implant design.

The goal of this was to compare the crestal bone levels adjacent to the Prevail implant reference point with and without platform change.

\section{Materials and Methods}

A comparative descriptive study of retrospective nature aimed to compare the level of the bone crest in two groups of prevail implants with platform change (test group) and prevail implants without platform change (control group). This study was derived from the project called "A Prospective, Randomized and Controlled Evaluation of the Osseotite CP4 CertainPrevail

Pablo CE | Volume 2; Issue 2 (2021) | JDHOR-2(2)-031 | Research Article 
Conical Implant for Crestal Bone Conservation", approved by the ETHICS Committee of CES University by Act \#36 of December 02, 2011.

The sample of this study included 26 patients who met the inclusion criteria, granted their authorization, by signing informed consent, to work with the clinical data obtained. In total there were 68 implants divided into two groups: prevail implant test group with platform change (34 implants) and control group with prevail implant without platform change (34 implants). X-rays obtained at the time of implant placement were used for measurement and 12 months later.

Bone crest level measurement: X-rays for both groups (implants with and without platform change) were taken using a parallelism technique with individualized film support in highresolution mode. Intraoral $\mathrm{x}$-rays were performed twice during the study: after implant placement and after 1 year of follow-up. The images were obtained in such a way that the implant-pillar interface was clearly visible. Prior to measurement, the parallelism of all intraoral x-rays was evaluated [24-26]. Radiological evaluation and measurements were performed using the RVG Windows Trophy software measurement program (7.0, Trophy Radiologie, Paris, France) (Fig. 1.) with an increase (20X) for the blind examiner [27-32]. Prior to the calculation of changes in the crestal bone, calibration of RVG images was performed using the calibration program in the same software. One study graded the software used to measure this research by reference to the diameter of the implant, 1848 measurements were taken over 3 different time periods. The average difference between measurements was $0.1 \mathrm{~mm}$ \pm 0.38 , and the average of three measurements was used. Bone loss and comparison between groups were reported separately, at distal and mesial sites (Fig. 2.) [30].

Once collected, the data were analyzed with the statistical software (IBM-SPSS version 21.0), taking the implants as a unit of analysis. The normality of bone loss distribution was assessed with the Shapiro Wilk test which did not show the normal distribution for the platformchanging group. Descriptive statistics such as mean, standard deviation and confidence interval were calculated for the mean. Relationships between age, implant position and mesial and distal bone loss were explored with respect to the two types of implants. A significance level of less than $5 \%$ was considered to determine whether the differences were statistically significant. 


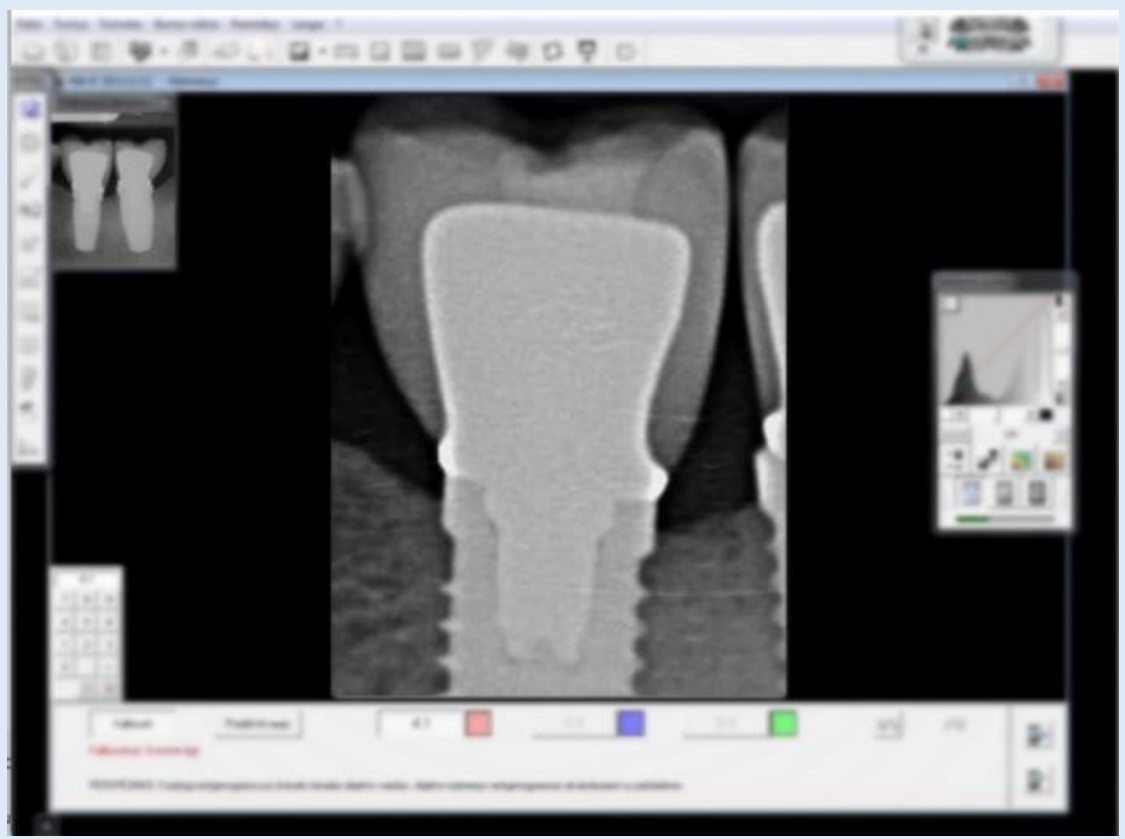

Figure 1: RVG Windows Trophy Software Measurement Program (7.0, Trophy Radiologie, Paris, France).

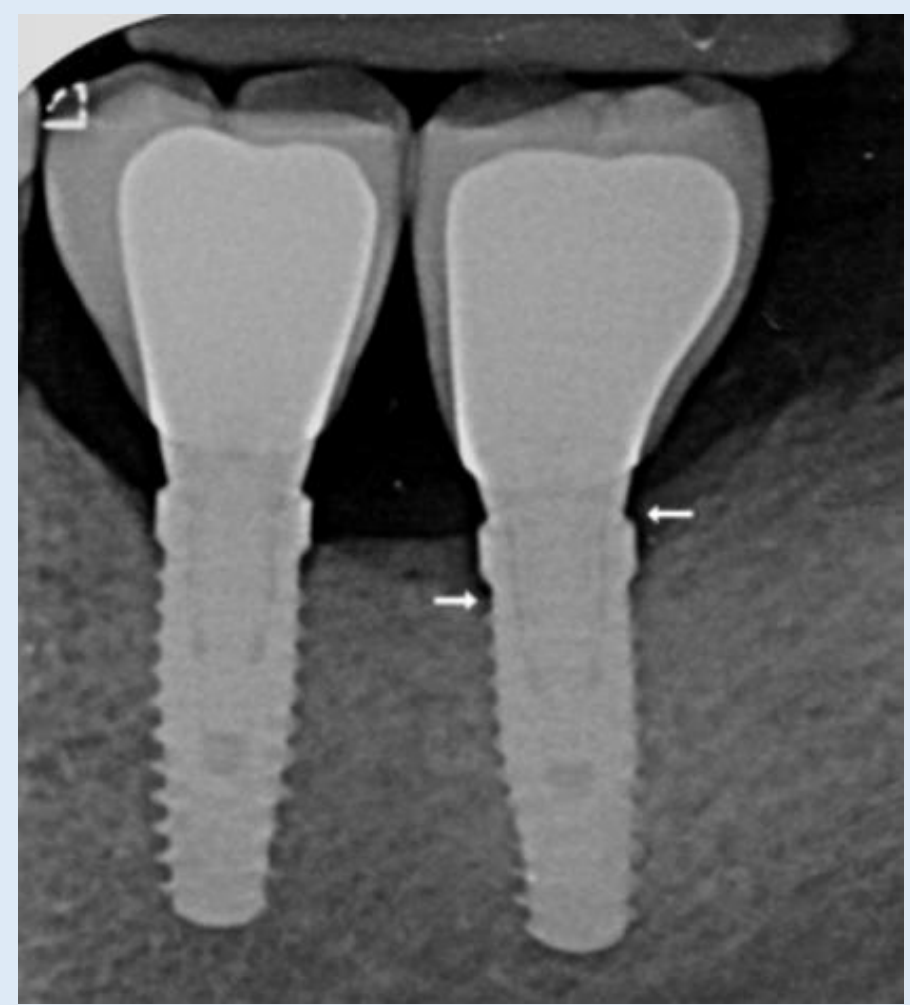

Figure 2: Measurement reference for implants.

Pablo CE | Volume 2; Issue 2 (2021) | JDHOR-2(2)-031 | Research Article

Citation: Pablo CE. Comparison of Crestal Bone Levels of Prevail Implants with Platform-Switched:

Following One Year. J Dental Health Oral Res. 2021;2(2):1-13. 


\section{Results}

For this study 26 patients met the inclusion criteria (19 women and 14 men) age ranged from 28 to 81 years with an average of $51.6 \pm 11.4$ years, they enrolled in the study. In total there were 68 implants divided into two groups: prevail implant test group with platform change (34 implants, 50\%) and control group with prevail implant without platform change (34 implants, $50 \%)$.

In a 12-month follow-up, all 26 patients were available for clinical and X-ray evaluation. All 68 implants remained clinically functional through the study. The cumulative survival rate in the 12-month follow-up was $100 \%$.

Table 1 shows the distribution of clinical variables according to the type of implant. The crestal position in both types of the implant was the highest prevalence, almost all implants had primary stability. The distribution of edentula zone adjacent to the implant, in mesial and distal was the same for both types of implants, as well as the presence of another implant. In contrast, the presence of adjacent tooth in the mesial area was most present in implants without platform change, while the presence of tooth in the distal area was presented more in implants with platform exchange.

Fig. 3 shows comparisons of bone loss in the mesial and distal areas between the groups (implant with and without platform change). Greater bone loss was obtained in the group of conventional implants for the mesial and distal zone with differences $\geq$ to $0.75 \mathrm{~mm}$, which means less bone loss in implants with platform change, with statistically significant differences at both the mesial and distal level (p-value $<0.01)$.

Fig. 4 shows the mesial and distal bone losses relative to adjacent structures in each type of implant with and without platform change. Implants without platform change found greater bone loss both mesial and distal in the edentula area, although without statistically significant differences. While implants with platform change showed greater bone loss at the distal level with the adjacent structure of the implant and no statistically significant differences. When comparing a bone loss with the adjacent structure between the two types of implants, only statistically significant differences were found in the tooth area at both the mesial level p-value of 0.014 and the distal p-value 0.043 (Table 1). 


\section{Type of Implant}

\begin{tabular}{|c|c|c|c|c|c|}
\hline Clinical Variabilities & Categories & $\begin{array}{c}\text { Without Exchange } \\
\mathbf{n}(\%)\end{array}$ & $\begin{array}{c}\text { With Exchange } \\
\text { n(\%) }\end{array}$ & $\begin{array}{l}\text { Total } \\
\text { n(\%) }\end{array}$ & $P$ value \\
\hline \multirow{3}{*}{ Position } & Crestal & $31(91,2)$ & $28(82,4)$ & $59(86,8)$ & \multirow[t]{3}{*}{0,562} \\
\hline & Subcrestal & $2(5,9)$ & $4(11,8)$ & $6(8,8)$ & \\
\hline & Supracrestal & $1(2,9)$ & $2(5,9)$ & $3(4,4)$ & \\
\hline \multirow[t]{2}{*}{ Stability } & No & $0(0)$ & $1(2,9)$ & $1(1,5)$ & \multirow[t]{2}{*}{0,314} \\
\hline & Yes & $34(100)$ & $33(97,1)$ & $67(98,5)$ & \\
\hline \multirow{3}{*}{$\begin{array}{c}\text { Adjacent Mesial Dental } \\
\text { Structure }\end{array}$} & Tooth & $26(76,5)$ & $22(64,7)$ & $48(70,6)$ & \multirow[t]{3}{*}{0,513} \\
\hline & Edentulous & $2(5,9)$ & $2(5,9)$ & $4(5,9)$ & \\
\hline & Implant & $6(17,6)$ & $10(29,4)$ & $16(23,5)$ & \\
\hline \multirow{3}{*}{$\begin{array}{c}\text { Adjacent Distal Dental } \\
\text { Structure }\end{array}$} & Tooth & $10(29,4)$ & $12(35,3)$ & $22(32,4)$ & \multirow[t]{3}{*}{0,806} \\
\hline & Edentulous & $15(44,1)$ & $15(44,1)$ & $30(44,1)$ & \\
\hline & Implant & $9(26,5)$ & $7(20,6)$ & $16(23,5)$ & \\
\hline
\end{tabular}

Table 1: Distribution of clinical variables according to the type of implant.

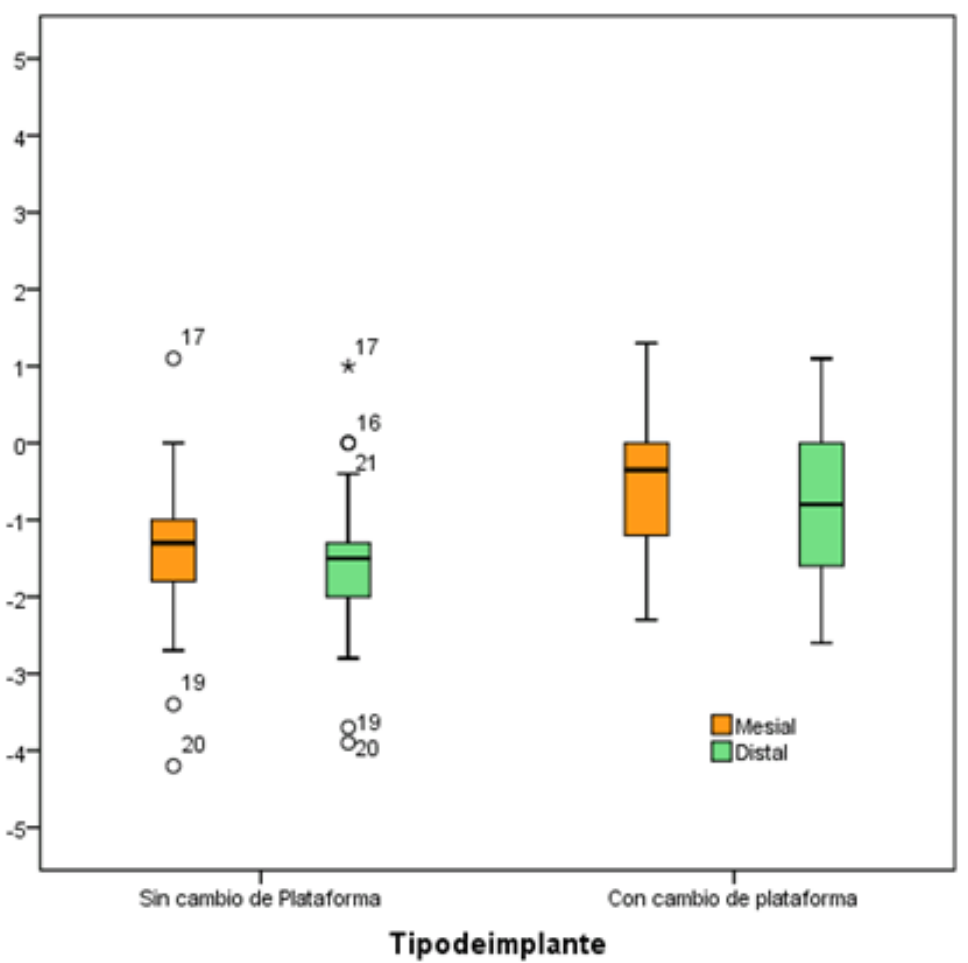

Figure 3: Comparisons of bone loss in mesial and distal areas, depending on the type of implant. 

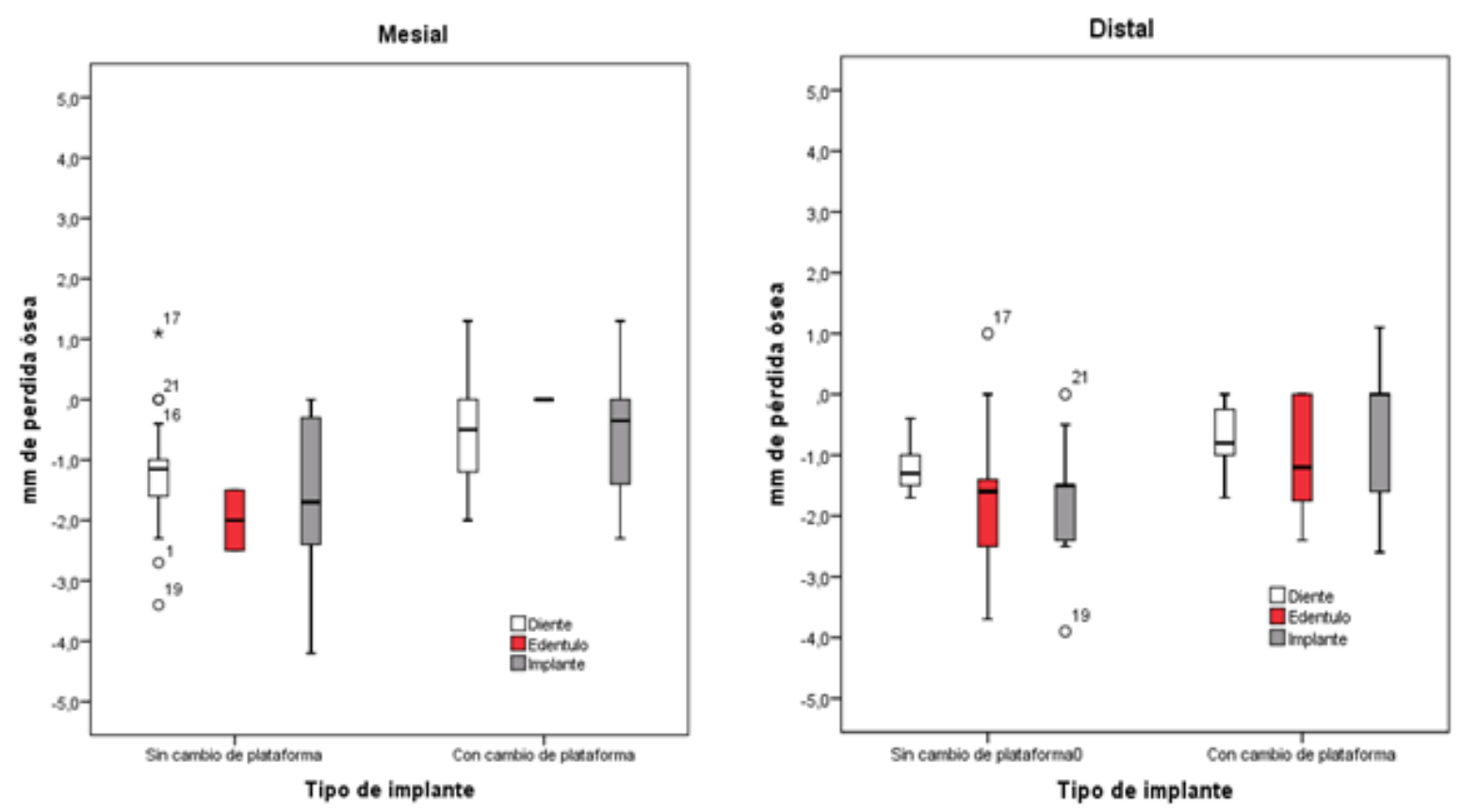

Figure 4: Distribution of mesial and distal bone loss according to an adjacent structure.

\section{Discussion}

The results of this study showed acceptable marginal bone levels, optimal stability, and aesthetics during the first 12 months of implant functional life, suggesting that crestal positioning of platform-changing implants is a viable option in prosthetic rehabilitation. The amount of bone remodelling was on average $0.78 \mathrm{~mm}$ and $0.75 \mathrm{~mm}$ at the mesial and distal levels respectively. These results consistent with others reported in the literature [33-38].

It has been widely reported that bone loss in the peri-implantar margin is conditioned by the location of the abutment/implant junction (UPI) relative to the alveolar crest, horizontally and vertically [34]. With platform change, the UPI moves horizontally to the center axis of the implant and is separated from the neighbouring bone. Therefore, bacterial filtration, micro movements, and stress concentration move away from the crest and bone-implant interface, resulting in less apical migration of the biological width and therefore less marginal bone resorption [34,35]. Recent meta-analysis reports the superiority of platform-changing implants in marginal bone preservation compared to conventional implantation, although some studies found no differences [36-38].

A strict relationship has been reported between the degree of crestal bone loss and the extent of inflammatory cell infiltration in the peri-implantar zone [39]. The intensity and location of the inflammatory infiltrate are related to the vertical insertion depth of the UPI with respect to 
the alveolar crest [40]. Some animal studies observed more crestal bone resorption around twopiece implants placed with UPI 1 to $2 \mathrm{~mm}$ below the bone crest compared to implants placed at $1 \mathrm{~mm}$ above or at bone crest level [41,42].

It is important to note that there are limitations, and inconclusive information, with respect to two-piece implants with platform change, being placed in a subcrestal position. In particular, some studies report placing the implant in a subcrestal position to have a positive influence on marginal changes in bone level while others do not confirm it [43-46]. In a human histological study, all implants placed subcrestally showed bone formed on the implant shoulder, while all equicrestal implants experienced 0.5 to $1.5 \mathrm{~mm}$ crestal bone resorption [47]. The variation between studies on the magnitude of the loss of the X-ray marginal bone is noticeable. A recent systematic review reported an average bone loss around implants placed at the subcrestal level from $0.05 \mathrm{~mm}$ to $1.40 \pm 0.50 \mathrm{~mm}$ after a follow-up of 6 to 60 months [48]. Discrepancies between the studies have been attributed to differences in implant-pillar connection, platform surface texture, surgical technique, interimplante distance, repeated disconnection/reconnection of the healing pillar and the initial thickness of the mucosa.

Current results are in line with those reported by Veis y cols and Fickl and col, and better than those of Cocchetto and cols, Crespi and cols and Cappiello and cols, there is no conclusive data available in the literature on the relative impact of implant-pillar configuration on marginal bone loss [49-54]. However, in a recent study, an internal abutment-implant configuration has been shown to be superior to an external connection in the preservation of marginal bone height $(0.24 \pm$ to $0.29 \mathrm{~mm}$ versus $1.14 \pm 0.54 \mathrm{~mm})$ [55].

Previous histological studies have shown that repeated manipulation of the abutment is associated with apical positioning of connective tissue and changes in the level of the crestal bone during the initial healing phase [56]. It is interesting to note that these harmful effects were reduced in platform-changing implants compared to matching implant-pillar configurations. In addition, in a clinical trial, a single change of abutment had no impact on the X-ray bone level [56].

It is documented that the quality of support, therapy, and control of peri-implant inflammation is of paramount importance for the long-term success of implant-retained restorations. It is noteworthy that periimplantary hard and soft tissues show similar behavior in healthy and periodontally compromised individuals. These findings are consistent with those of previous research [54,55]. These showed that marginal bone loss around implants in patients with treated periodontitis is minimal if they receive controlled supportive periodontal therapy and periodontal index is individually monitored [56]. 
This study has some limitations to consider, such as sample size, studies should be considered by increasing the number of subjects participating in each group (test and control) to have a representative sample of the population and control possible desertions. Also, consider using cone-beam type tomography and associated software for more accurate measurement of bone crest levels.

\section{Conclusion}

The use of implants with platform-changing pillars seems to limit the loss of hard tissue, preserving the bone crest around it, also allowing the stability of the periimplantary soft tissue for the specific implant system used.

Other longitudinal studies, with larger sample sizes and longer follow-up, should confirm the results presented here.

\section{Conflict of Interest Disclosure}

There is no conflict of interest and no funding sources supporting the study.

\section{References}

1. Sanz M, Ivanoff CJ, Weingart D, Wiltfang J, Gahlert M, Cordaro L, et al. Clinical and radiologic outcomes after submerged and transmucosal implant placement with two-piece implants in the anterior maxilla and mandible: 3-year results of a randomized controlled clinical trial. Clin Implant Dent Relat Res. 2015; 17:23446.

2. Klein MO, Bijelic A, Toyoshima T, Götz H, Von Koppenfels RL, Al-Nawas B, et al. Long-term response of osteogenic cells on micron and submicron-scale-structured hydrophilic titanium surfaces: sequence of cell proliferation and cell differentiation. Clin Oral Implants Res. 2010;21(6):642-9.

3. Block MS. Immediate loading of the edentulous mandible. Color Atlas of Dental Implant Surg. 2015;3:1645.

4. Kanayama T, Horii K, Senga Y, Shibuya Y. Crestal approach to sinus floor elevation for atrophic maxilla using platelet-rich fibrin as the only grafting material: a 1-year prospective study. Implant Dent. 2016;25:328.

5. Lazzara RT, Testori T, Trisi P, Porter SS, Weinstein RL. A human histologic analysis of osseotite and machined surfaces using implants with 2 opposing surfaces. Int J Periodontics Restorative Dent. 2013;19(2):117-29.

6. Toscano P, Toscano C, Del Fabbro M. Mini-invasive implant placement in combination with maxillary sinus membrane perforation during transcrestal sinus floor elevation: A retrospective study. Int $\mathbf{J}$ Periodontics Restorative Dent. 2016;36:199-211.

7. Gehrke SA, Tavares da Silva Neto U. Does the time of osseointegration in the maxilla and mandible differ? J Cranio-fac Surg. 2014;25(6):2117-20.

8. Gupta R, Weber KK. Dental, Implants. Treasure Island (FL): StatPearls Publishing 2018. [Last accessed on August 17, 2021] https://www.ncbi.nlm.nih.gov/books/NBK470448/

Pablo CE | Volume 2; Issue 2 (2021) | JDHOR-2(2)-031 | Research Article 
9. Diz P, Scully C, Sanz M. Dental implants in the medically compromised patient. J Dent. 2013;41(3):195-206.

10. Kate MA, Palaskar S, Kapoor P. Implant failure: A dentist's nightmare. J Dent Implant. 2016;6:51-6.

11. Schimmel M, Müller F, Suter V, Buser D. Implants for elderly patients. Periodontol. 2017;73(1):228-40.

12. Tagliareni JM, Clarkson E. Basic concepts and techniques of dental implants. Dent Clin North Am. 2015;59(2):255-64.

13. Neves J, de AraújoNobre M, Oliveira P, Martins Dos Santos J, Malo P. Risk factors for implant failure and peri-implant pathology in systemic compromised patients. J Prosthodont. 2016.

14. Grisar K, Sinha D, Schoenaers J, Dormaar T, Politis C. Retrospective analysis of dental implants placed between 2012 and 2014: indications, risk factors, and early survival. Int J Oral Maxillofac Implants. 2017;32(3):649-54.

15. Shemtov-Yona K, Rittel D. An overview of the mechanical integrity of dental implants. Biomed Res Int. 2015;2015:547384. .

16. Von Wilmowsky C, Moest T, Nkenke E, Stelzle F, Schlegel KA. Implants in bone: part I. A current overview about tissue response, surface modifications and future perspectives. Oral Maxillofac Surg. 2014;18:243-57.

17. Barfeie A, Wilson J, Rees J. Implant surface characteristics and their effect on osseointegration. Br Dent $\mathrm{J}$. 2015;218:E9.

18. Van Velzen FJ, Ofec R, Schulten EA, Ten Bruggenkate CM. 10-year survival rate and the incidence of periimplant disease of 374 titanium dental implants with a SLA surface: a prospective cohort study in 177 fully and partially edentulous patients. Clin Oral Implants Res. 2015;26:1121-8.

19. Chappuis V, Buser R, Bragger U, Bornstein MM, Salvi GE, Buser D. Long-term outcomes of dental implants with a titanium plasma-sprayed surface: a 20-year prospective case series study in partially edentulous patients. Clin Implant Dent Relat Res. 2013;15:780-90.

20. Degidi M, Nardi D, Piattelli A. 10-year follow-up of immediately loaded implants with TiUnite porous anodized surface. Clin Implant Dent Relat Res. 2012;14:828-38.

21. Mozzati M, Gallesio G, Del Fabbro M. Long-term (9-12 years) outcomes of titanium implants with an oxidized surface: a retrospective investigation on 209 implants. J Oral Implantol. 2015;41:437-43.

22. Pozzi A, Mura P. Clinical and radiologic experience with moderately rough oxidized titanium implants: up to 10 years of retrospective follow-up. Int J Oral Maxillofac Implants. 2014;29:152-61.

23. Meng HW, Chien EY, Chien HH. Dental implant bioactive surface modifications and their effects on osseointegration: a review. Biomark Res. 2016;4:24.

24. Aguilar-Barojas, S. Fórmulas para el cálculo de la muestra en investigaciones de salud. Salud en Tabasco. 2005;11(1-2):333-8.

25. García-García JA, Reding-Bernal A, López-Alvarenga JC. Calculation of the sample size in research in medical education. Res Med Edu. 2013;2 (8): 217-24.

26. Lindquist LW, Rockler B, Carlsson GE. Bone resorption around fixtures in edentulous patients treated with mandibular fixed tissue- integrated prostheses. J Prosthet Dent. 1998;1:59-63.

27. Puisys A, Tomas L. The influence of mucosal tissue thickening on crestal bone stability around bone-level implants: A prospective controlled clinical trial. Clin Oral Implants Res. 2015;26(2):123-9.

28. Linkevicius T, Puisys A, Steigmann M, Vindasiute E, Linkeviciene L. Influence of vertical soft tissue thickness on crestal bone changes around implants with platform switching: a comparative clinical study. Clin Implant Dent Relat Res. 2015;17(6):1228-36.

29. Linkevicius T, Puisys A, Svediene O, Linkevicius R, Linkeviciene L. Radiological comparison of lasermicrotextured and platform-switched implants in thin mucosal biotype. Clin Oral implants Res. 2015;26(5):599-605.

30. Linkevicius T, Puisys A, Linkeviciene L, Peciuliene V, Schlee M. Crestal bone stability around implants with horizontally matching connection after soft tissue thickening: a prospective clinical trial. Clin Implant Dent Relat Res. 2015:17(3):497-508.

Pablo CE | Volume 2; Issue 2 (2021) | JDHOR-2(2)-031 | Research Article 
31. Huda W, Rill LN, Benn DK, Pettigrew JC. Comparison of a photostimulable phosphor system with film for dental radiology. Oral Surg Oral Med, Oral Pathol, Oral Radiol Endod. 1997;83.6:725-31.

32. Rotundo R, Pagliaro U, Bendinelli E, Esposito M, Buti J. Long-term outcomes of soft tissue augmentation around dental implants on soft and hard tissue stability: a systematic review. Clin Oral Implants Res. 2015;26:123-38.

33. Degidi M, lezzi G, Scarano A, Piattelli A. Immediately loaded titanium implant with a tissuestabilizing/maintaining design ('beyond platform switch') retrieved from man after 4 weeks: A histological and histomorphometrical evaluation. A case report. Clin Oral Implants Res. 2008;19:276-82.

34. Maeda Y, Miura J, Taki I, Sugo M. Biomechanical analysis on platform switching: Is there any biomechanical rationale? Clin Oral Implants Res. 2007;18:581-4.

35. Canullo L, Fedele GR, lannello G, Jepsen S. Platform switching and marginal bone-level alterations: The results of a randomizedcontrolled trial. Clin Oral Implants Res. 2010;21:115-21.

36. Linkevicius T, Apse P, Grybauskas S, Pruisys A. Influence of thin mucosal tissues on crestal bone stability around implants with platform switching: A 1-year pilot study. J Oral Maxillofac Surg. 2010;68:2272-7.

37. Crespi R, Cappare P, Gherlone E. Radiographic evaluation of marginal bone levels around platform-switched and non-plat- formswitched implants used in an immediate loading protocol. Int J Oral Maxillofac Implants. 2009;24:920-6.

38. Enkling N, Johren P, Klimberg V, Bayer S, Mericske-Stern R, Jepsen S. Effect of platform switching on periimplant bone levels: A randomized clinical trial. Clin Oral Implants Res. 2011;22:1185-92.

39. Ericsson I, Persson LG, Berglundh T, Marinello CP, Lindhe J, Klinge B. Different types of inflammatory reactions in peri-implant soft tissues. J Clin Periodontol. 1995;22:255-61.

40. Broggini N, McManus LM, Hermann JS, Medina R, Schenk RK, Buser D, et al. Peri-implant inflammation defined by the implant-abutm ENT interface. J Dent Res. 2006;85:473-8.

41. Todescan FF, Pustiglioni FE, Imbronito AV, Albrektsson T, Gioso M. Influence of the microgap in the periimplant hard and soft tissues: A histomorphometric study in dogs. Int $\mathrm{J}$ Oral Maxillofac Implants. 2002; 17:467-72.

42. Pontes AE, Ribeiro FS, da Silva VC, Margonar R, Piattelli A, Cirelli JA, et al. Clinical and radiographic changes around dental implants inserted in different levels in relation to the crestal bone, under different restoration protocols, in the dog model. J Periodontol. 2008;79:486-94.

43. Jung RE, Jones AA, Higginbottom FL, Wilson TG, Schoolfield J, Buser D, et al. The influence of nonmatching implant and abutment diameters on radiographic crestal bone levels in dogs. J Periodontol. 2008;79:260-70.

44. Cochran DL, Bosshardt DD, Grize L, Higginbottom FL, Jones AA, Jung RE, et al. Bone response to loaded implants w ith non-matching implant-abutment diameters in the canine mandible. J Periodontol. 2009;80:60917.

45. Fickl S, Zuhr O, Stein JM, Hurzeler MB. Peri-implant bone level around implants with platform-switched abutments. Int J Oral Maxillofac Implants. 2010;25:577-81.

46. Veis A, Parissis N, Tsirlis A, Papadeli C, Marinis G, Zogakis A. Evaluation of peri-implant marginal bone loss using modified abutment connections at various crestal level placements. Int J Periodontics Restorative Dent. 2010;30:609-17.

47. Degidi M, Perrotti V, Shibli JA, Novaes AB, Piattelli A, lezzi G. Equicrestal and subcrestal dental implants: A histologic and histomorphometric evaluation of nine retrieved human implants. J Periodontol. 2011;82:708-15.

48. Alonso-González R, Aloy-Prósper A, Peñarrocha-Oltra D, Peñarrocha-Diago MA, Peñarrocha-Diago M. Marginal bone loss in relation to platform switching implant insertion depth: An update. J Clin Exp Dent 2012;4:173-9.

49. Chou CT, Morris HF, Ochi S, Walker L, DesRosiers D. AICRG, Part II: Crestal bone loss associated with the Ankylos implant: Loading to 36 months. J Oral Implantol. 2004;30:134-43.

Pablo CE | Volume 2; Issue 2 (2021) | JDHOR-2(2)-031 | Research Article

Citation: Pablo CE. Comparison of Crestal Bone Levels of Prevail Implants with Platform-Switched: Following One Year. J Dental Health Oral Res. 2021;2(2):1-13.

DOI: http://dx.doi.org/10.46889/JDHOR.2021.2206 
50. Crespi R, Cappare P, Gherlone E. Radiographic evaluation of marginal bone levels around platform-switched and non-plat- form switched implants used in an immediate loading protocol. Int J Oral Maxillofac Implants. 2009;24:920-6.

51. Schwarz F, Alcoforado G, Nelson K, Schaer A, Taylor T, Beuer F, et al. Impact of im plant-abutment connection, positioning of the machined collar/microgap, and platform switching on crestal bone level changes. Camlog Foundation Consensus Report. Clin Oral Implants Res. 2013;24:1-3.

52. Koo KT, Lee EJ, Kim JY, Seol YJ, Han JS, Kim TI, et al. The effect of internal versus external abutment connection modes on crestal bone changes around dental implants: A radiographic analysis. J Periodontol. 2012;83:1104-9.

53. Iglhaut G, Becker K, Golubovic V, Schliephake H, Mihatovic I. The impact of dis-/reconnection of laser microgrooved and machined implant abutments on soft and hard tissue healing. Clin Oral Implants Res. 2013;24:391-7.

54. Koutouzis T, Fetner M, Fetner A, Lundgren T. Retrospective evaluation of crestal bone changes around implants with reduced abutment diameter placed non-submerged and at a subcrestal position: The effect of bone grafting at implant placement. J Periodontol. 2011;82:234-42.

55. Jo DW, Yi YJ, Kwon MJ, Kim YK. Correlation between interimplant distance and crestal bone loss in internal connection implants with platform switching. Int J Oral Maxillofac Implants. 2014;29:296-302.

56. Aimetti M, Ferrarotti F, Mariani GM, Ghelardoni C, Romano F. Soft tissue and crestal bone changes around implants with platform-switched abutments placed nonsubmerged at subcrestal position: a 2-year clinical and radiographic evaluation. Int J Oral Maxillofac Implants. 2015;30:1369-77. 